\title{
Electrochemical Treatment of Disperse Blue1 Dyes in simulated textile Effluent: Parameter Optimization Method
}

Ezeigbo Ephraim chidi' ${ }^{1}$, Festus Kelechi Williams ${ }^{1}$, Ordu Eze Williams ${ }^{2}$ and Fesomade Kayode Ibrahim ${ }^{3}$

${ }^{1}$ Chemistry Department, Federal university of Technology, Owerri, Nigeria

${ }^{2}$ Enviromental Science Department, Federal University of Technology, Owerri, Nigeria

${ }^{3}$ Material and Metallurgical Engineering Department, Federal University of Technology, Akure, Nigeria

\begin{abstract}
.
Electrochemical oxidation for Disperse blue 1 dye wastewater simulated in the laboratory, was investigated in this study using Graphite materials as the electrodes. The experiment was carried out in a batch process in a laboratory-scale that was analyzed at every $30 \mathrm{~min}$ regular intervals, for a total period of $180 \mathrm{~min}$. the results were reported in terms of colour removal for different parameters of initial concentrations $(50 \mathrm{mg} / \mathrm{L}, 95 \mathrm{mg} / \mathrm{L}$, and $145 \mathrm{mg} / \mathrm{L}$ ), electrode geometry (plain and cylindrical), $\mathrm{pH}(4,7,9)$, current intensity $(1 \mathrm{~A}, 3 \mathrm{~A})$, and temperature $\left(28^{\circ} \mathrm{C}\right.$, $50^{\circ} \mathrm{C}$ ). For the different initial concentrations, Color was reduced by $85.4 \%, 67.4 \%$ and $67.8 \%$ respectively. More also the plain graphite electrodes showed a comparatively higher efficiency of colour removal than the cylindrical graphite electrodes. Furthermore, we observed a decrease in colour removal when the $\mathrm{pH}$ of the effluent was increased from 4 to 9 showing an efficiency of 58.7\%, 54.6\% respectively. Current intensity and temperature showed similar variations. UV-Vis study confirmed that the proposed electrochemical degradation process could be an effective method for the degradation of textile dye effluent.
\end{abstract}




\section{Introduction}

Textile industries present one of the basic need for living (clothing) thereby making it an important industry in the human race. However, the industry is not without its cons. Textile industries have been one of the major sources of water pollution, this is due consumption of large volumes of water and the resulting discharge of large quantities of coloured dye effluents as a result of processes which include pre-treatment, dyeing, printing and finishing [1-3]. The exegesis of wastewater discharged from textile industries presents a toxic suspended and dissolved solids substance [4]. Analysis on wastewaters shows the presence of sodium and Chromium in high concentration, also heavy metals including lead copper, zinc iron, sulphates were present. Textile processing industries largely employ the use of Azo dyes in their operations, most of which are aromatic hydrocarbons, a derivative of benzene, toluene, naphthalene, phenol and aniline [59]. Azo dyes are the most important group of synthetic colourants that are extensively used in textile, pharmaceutical and printing industries. They are an important group of xenobiotic compounds and are recalcitrant in biodecolourization process and pose toxicity (Lethal effect, Genotoxicity, mutagenicity and carcinogenicity) to aquatic organisms (fish, alga, bacteria etc.) as well as animals, thus the need for degrading the impact of Azo dye arises [10-11].

Since wastewaters from textile industries may find their way back to the water bodies, it is of high interest to researchers to find an efficient and economic viable way of removing pollutants (majorly dye) from textile industries wastewaters. Over the years, different approaches have been developed, this includes physical, biological and electrochemical technique for the treatment of wastewaters. The physical method involves adsorption process and it is expensive and a bit complex to execute, on the other hand, the biological method is easier and more economical, but it suffers from the drawback of lengthy processing time. The chemical method generates large quantity of sludge which will be subjected to another treatment. The physicochemical methods include flocculation combined with floatation, electro-floatation, membrane filtration, electro-kinetic coagulation, ion-exchange, irradiation, precipitation, ozonation and physiochemical treatment method involving the use of activated carbon [12-15]. However these technologies are 
usually inefficient in the removal of colour, little adaptable to a wide range of dye wastewaters, generally lead to the production of secondary pollution and so many more challenges. It should be more economical and environmentally acceptable to use a decolourization technique that is efficient in the removal of colour, less expensive and environmental friendly [16]. The electrochemical technique of treating wastewaters containing organic pollutants has drawn attention, this is mainly for its merits over other techniques, and these include environmental friendliness, technical feasibility, cost-effectiveness, versatility, ease of operation, energy efficiency, low-temperature requirement and great outputs [17-18]].

The electrochemical method used in this research achieved a high percent decolourization. The parameters in the electrochemical setup include the geometry of the Anode and cathode, initial dye concentration, current intensity, $\mathrm{pH}$, and temperatures among others. The electrochemical technique employs an oxidation method to breakdown the resistant organic dye compound. It involves the adsorption of the pollutant to the anode [19].

\section{Materials and methods}

All the chemicals used in the study were of analytic reagent (AR) grade. The Disperse blue 1 dye used in this study was obtained from Aldrich Chemical Company Ltd (USA). This anthraquinone dye in this study was used to simulate textile effluent from most textile industries. The dye with chemical formula $\mathrm{C}_{14} \mathrm{H}_{12} \mathrm{~N}_{4} \mathrm{O}_{2}$ has a molar mass of $268.278 \mathrm{~g} / \mathrm{mol}$ with a maximum absorbance wavelength of $615 \lambda \mathrm{m}$. The decolourization was carried out at a temperature of $25^{\circ} \mathrm{C}(298 \mathrm{~K})$ in $500 \mathrm{ml}$ flask, a calibration curve of $50 \mathrm{ml}, 95 \mathrm{ml}$ and $145 \mathrm{ml}$; variation of current was also studied.

\subsection{Experimental set-up for the electrochemical process}

The set-up for the electrochemical process is represented in figure 1. The set-up consists of a glass beaker of $500 \mathrm{ml}$ capacity with a PVC lid in a circular shape, having provision to fit a cathode and Anode in a dimension of $(7 \mathrm{~cm} \times 3 \mathrm{~cm} \times 0.2$ $\mathrm{cm})$ with a distance of $(5 \mathrm{~cm})$ between the cathode and Anode. The supporting electrolytes such as $\mathrm{NaCl}(10 \mathrm{ml})$ were added to the electrolytes solution which increased the conductivity of the dye effluent and reduced the electrolysis time. DC 
power supply $(30 \mathrm{~V} / 5 \mathrm{~A})$ was set at $5 \mathrm{~V}, 1 \mathrm{~A}$ and kept under agitation using a magnetic stirrer. During this process, samples were collected through the hollow PVC lid at 30 minutes intervals and added into sealed test tubes, the extracted samples for each concentration $50 \mathrm{ml}, 95 \mathrm{ml}$, and $145 \mathrm{ml}$ were analyzed using a UV spectrophotometer and origin pro 8.0 software was used for experimental data plotting. The experimental device is shown in Figure 1.

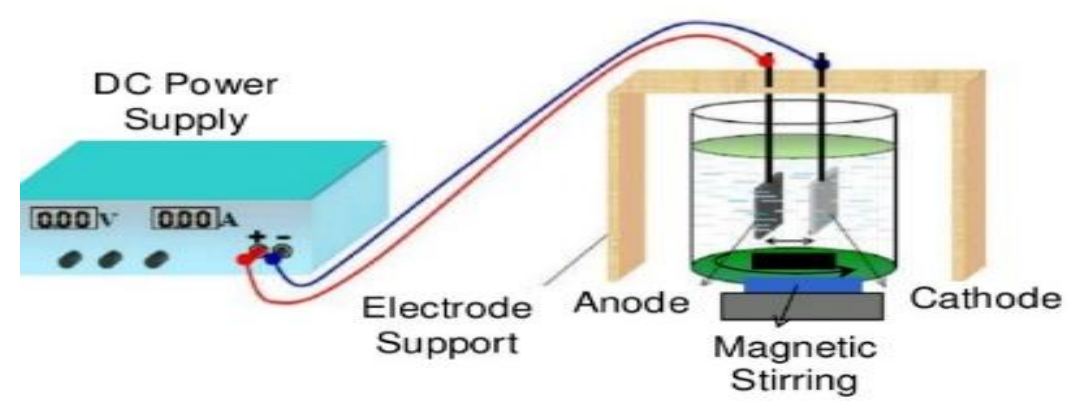

Fig 1. Electrochemical treatment diagram

\section{2 pH measurement}

The initial and final $\mathrm{pH}$ of the best and least decolourized concentration was determined using a $\mathrm{pH}$ meter.

The $\mathrm{pH}$ was adjusted to 4,7 and 9 for the two concentrations. A $0.1 \mathrm{M} \mathrm{NaOH}$ solution was used to increase the $\mathrm{pH}$ while a $0.1 \mathrm{M}$ of $\mathrm{H}_{2} \mathrm{SO}_{4}$ solution w used to reduce the $\mathrm{pH}$ to the required level

\subsection{Spectroscopic analysis}

The decolourization process was studied via spectroscopy analysis, where the absorbance of the initial dye $\left(\mathrm{Ab}_{\mathrm{so}}\right)$ was compared with the absorbance of the samples collected during the treatment $\left(\mathrm{Ab} \mathrm{b}_{\mathrm{st}}\right)$. The absorbance was measured with the UV spectrophotometer (L1-722) at wavelength $615 \lambda \mathrm{m}$. UV employed to measure the optical density and electrochemical treatment of percentage decolourization as shown in the equations 
$\mathrm{D}(\%)=\frac{\left(A b_{s o}\right)-\left(A b_{s t}\right)}{\left(A b_{s o}\right)} \times 100$

Where;

$\mathrm{D} \%=$ percentage of colour removal

$\mathrm{Ab}_{\mathrm{so}}=\mathrm{Absorbance}$ at 0min (initial absorbance)

$\mathrm{Ab}_{\mathrm{st}}=$ Absorbance value at final time.

\section{Results and discussion}

\subsection{Effect of initial concentration.}

Figure 2 shows the trend of decolourization of the simulated disperse blue 1 dye effluent at three different initial concentrations $(50 \mathrm{mg} / \mathrm{L}, 95 \mathrm{mg} / \mathrm{L}$, and $145 \mathrm{mg} / \mathrm{L})$ over time. It can be observed from the plot the decolourization rate varies differently with the initial dye concentration. The higher the concentration of the dye in the effluent solution, the lower the decolourization rate will be. While the lower the initial concentration, the higher the decolourization. . After 180 minutes of effluent treatment, the percentage decolourization of the $50 \mathrm{mg} / \mathrm{L}$ dye effluent is recorded at $85.4 \%$, compared to $67.4 \%$ and $67.8 \%$ for $95 \mathrm{mg} / \mathrm{L}$ and $145 \mathrm{mg} / \mathrm{L}$ dye effluent respectively. This observation is consistent with reports from other work. . The reason for this observed pattern is because as the amount of dye material increases, the amount of unit electrode treatment increases. However, more organic molecules cover the anode surface is not conducive to the production of $\cdot \mathrm{OH}$, so the degradation efficiency will be reduced [20]. 


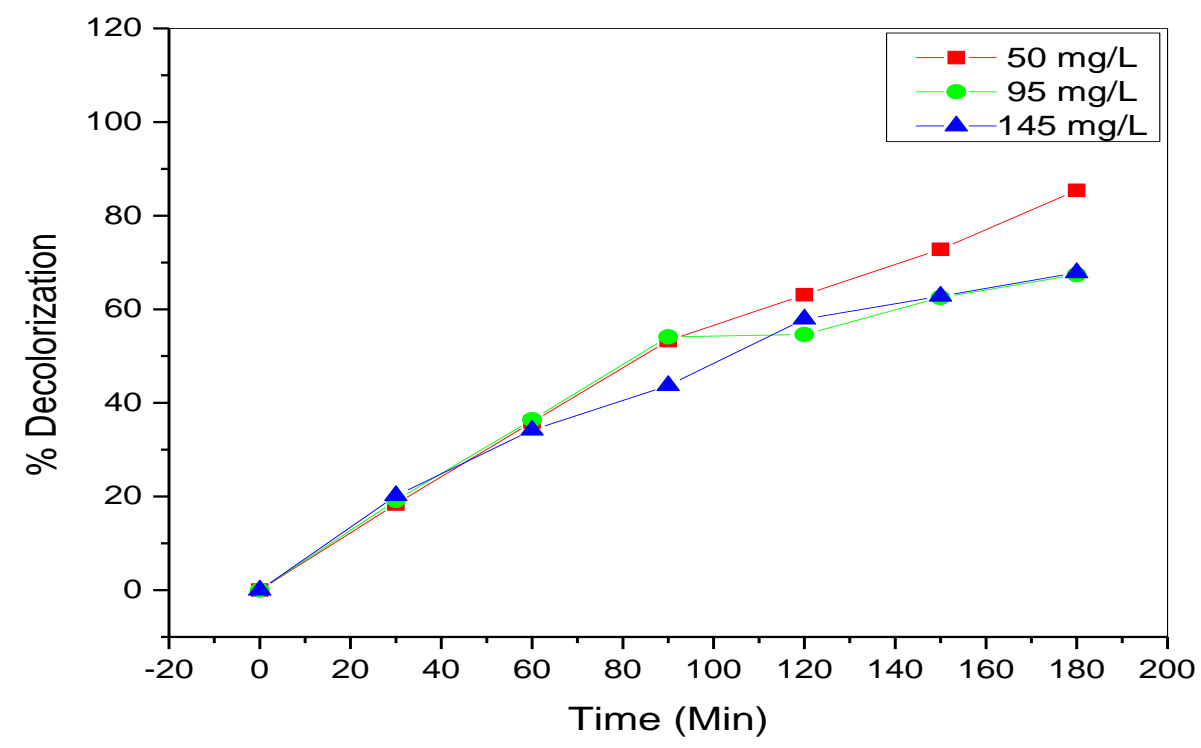

Fig. 2:\%Decolourization of $50 \mathrm{mg} / \mathrm{L}, 95 \mathrm{mg} / \mathrm{L}$, and $145 \mathrm{mg} / \mathrm{L}$ concentration on disperse blue dye (current $=1 \mathrm{~A}$, voltage $=5 \mathrm{~V}$, electrolyte $\left.=0.05 \mathrm{molL}^{-1}\right)$ using plane graphite electrodes

\subsection{Effect of electrode Geometry}

During this study, the effect of the electrode structure on the treatment process was investigated. This was done by exchanging the initially plane-shaped electrodes for cylindrical; shaped electrodes, while keeping every other parameter same as that using the plane electrode including electrode material (graphite). At the end of the treatment time (180 minutes), the following result was gotten and plotted as seen in Fig. below. 


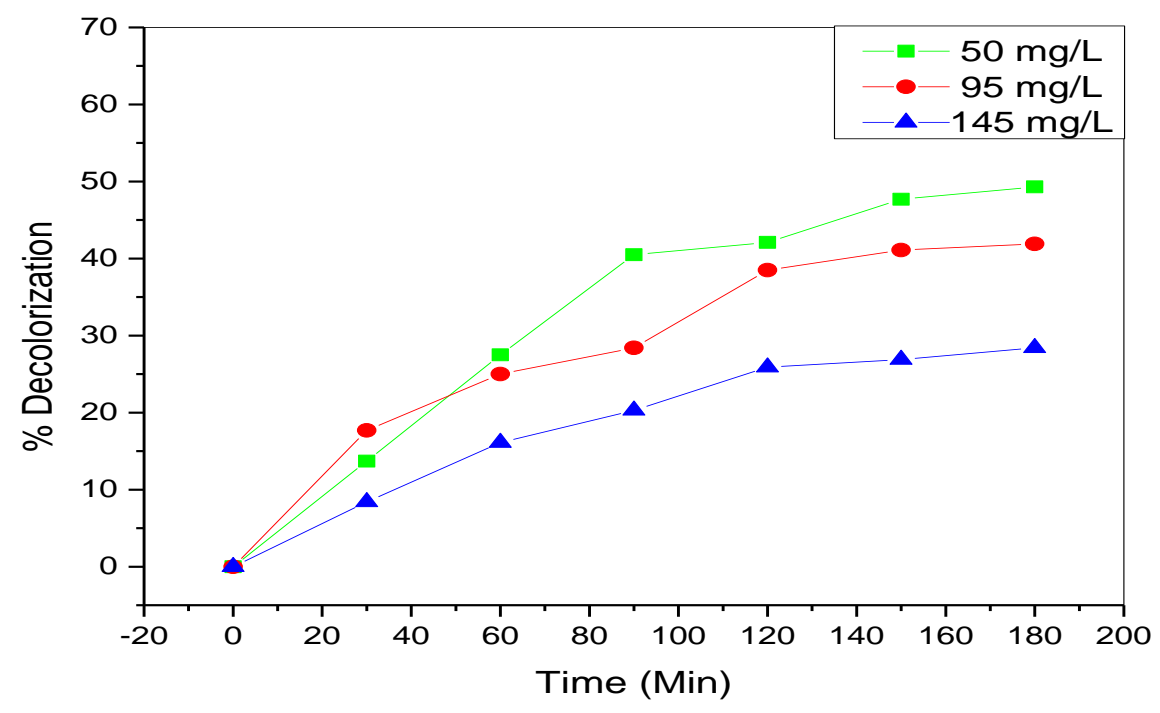

Fig. 3:\% Decolourization of $50 \mathrm{mg} / \mathrm{L}, 95 \mathrm{mg} / \mathrm{L}$, and $145 \mathrm{mg} / \mathrm{L}$ concentration on disperse blue dye (current $=1 \mathrm{~A}$, voltage $=5 \mathrm{~V}$, electrolyte $=0.05 \mathrm{molL}^{-1}$ ) using cylindrical graphite electrodes

Here, it can be noticed that the rate of decolourization using a hollow cylindrical electrode is comparatively small with respect to using a plane electrode. After 180 minutes of electrochemical treatment, a maximum percentage decolourization of $49 \%$ is recorded for the lowest initial dye concentration $(50 \mathrm{mg} / \mathrm{L})$ compared to $85.4 \%$ read using the plane electrode. This depicts that the shape of the electrode affects the degradation of dye in the effluent during electrochemical treatment. It is expected that the large surface area offered by the plane electrode will lead to high conductivity and current output into the effluent.

Hence, there will be a generation of more electrooxidants to cause more degradation of the dye compound.

\subsection{Effect of $p H$}

The $\mathrm{pH}$ of a solution is another important parameter that affects the efficiency of colour removal. This efficiency can be increased by increasing or decreasing the $\mathrm{pH}$ of the solution depending on the nature of the dye substrate and effluent.

Figure 2 shows how the decolourization rate of a given concentration of Disperse blue 1 dye effluent vary at different $\mathrm{pH}(4,7,9)$. It can be seen from the figure that when the $\mathrm{pH}$ is 4 , the decolourization rate is maximum; assuming a value of about $58.7 \%$ compared to values of $54.6 \%$ and $48 \%$ for $\mathrm{pH} 7$ and $\mathrm{pH} 9$ respectively. This indicates that the optimization of this process is more efficient in acidic conditions 
than in neutral and basic conditions. This observation stems from the fact that in that the stronger the acidity condition is, the stronger the hydroxyl radical is, the higher the oxygen evolution potential is, and the degradation effect of the acidic condition is better than the alkaline; On the other hand, the presence of a large amount of $\mathrm{OH}$ - in alkaline conditions favours the formation of hydroxyl radicals, which together contribute to the effect of $\mathrm{pH}$ on the decolourization rate [21].

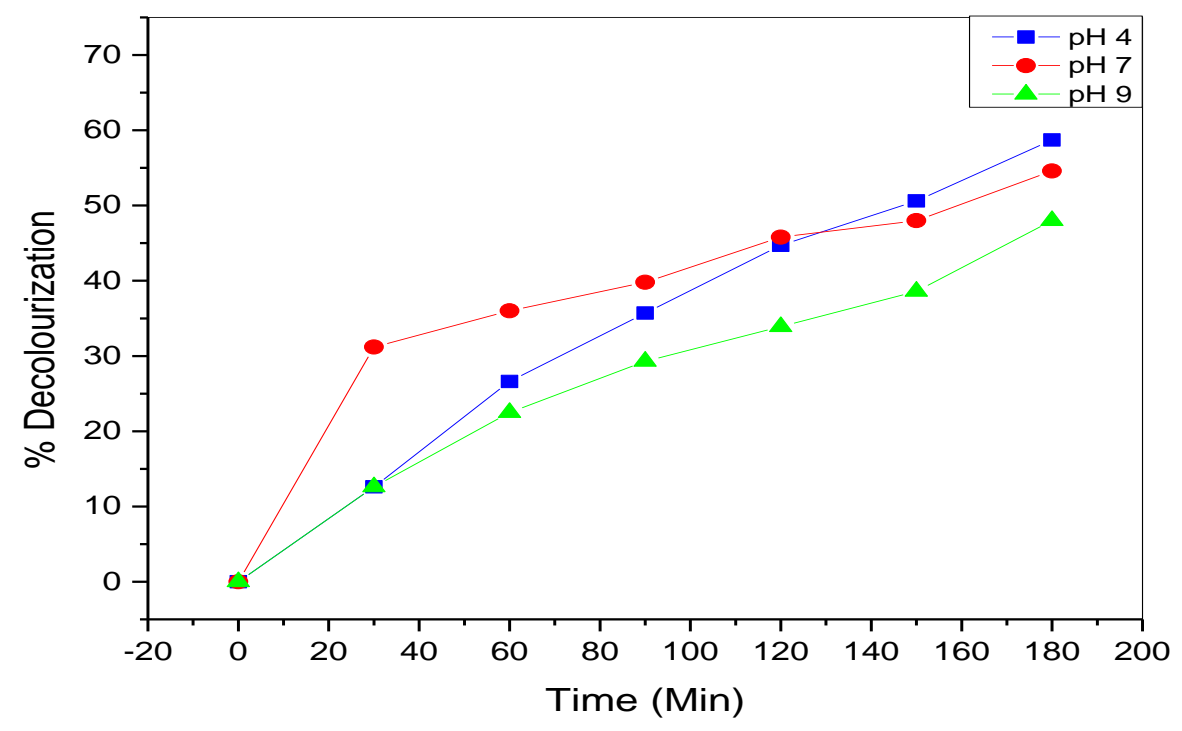

Fig. 4: \% Decolourization at 50mg/L Disperse Blue1 at $\mathrm{pH} \mathrm{4,7}$ and 9 (current $=1 \mathrm{~A}$, voltage $=$ $5 \mathrm{~V}$, electrolyte $=0.05 \mathrm{molL}^{-1}$ ) using plain graphite electrode.

\subsection{Effect of Temperature}

The effect of operating temperature was studied on the $50 \mathrm{mg} / \mathrm{L}$ dye effluent sample because this concentration showed a steady and consistent behavioural pattern to the effects of the rate of decolourization. Here, the experiment was conducted at two distinct temperatures, $28^{\circ} \mathrm{C}$ and $50^{\circ} \mathrm{C}$. From the figure 4 , the $28^{\circ} \mathrm{C}$ led in decolourization efficiency, while the $50^{\circ} \mathrm{C}$ lagged throughout the duration of the reaction, as the lower temperature showed a higher percentage decolourization of $95 \%$ while the $50{ }^{\circ} \mathrm{C}$ recorded a lower reading of $75 \%$. Conclusively, the percentage decolourization clearly and markedly decreased as the operating temperature of the treatment increased from $28^{\circ} \mathrm{C}$ to $50^{\circ} \mathrm{C}$. This permits us to aver that lower temperature favours the degradation of the dye. The reason for this 
decrease in the percentage decolourization of this dye as the operating temperature increases is because of the decrease in the generation of chlorine/hypochlorite necessary to effect the degradation of the dye as the operating temperature increases [22].

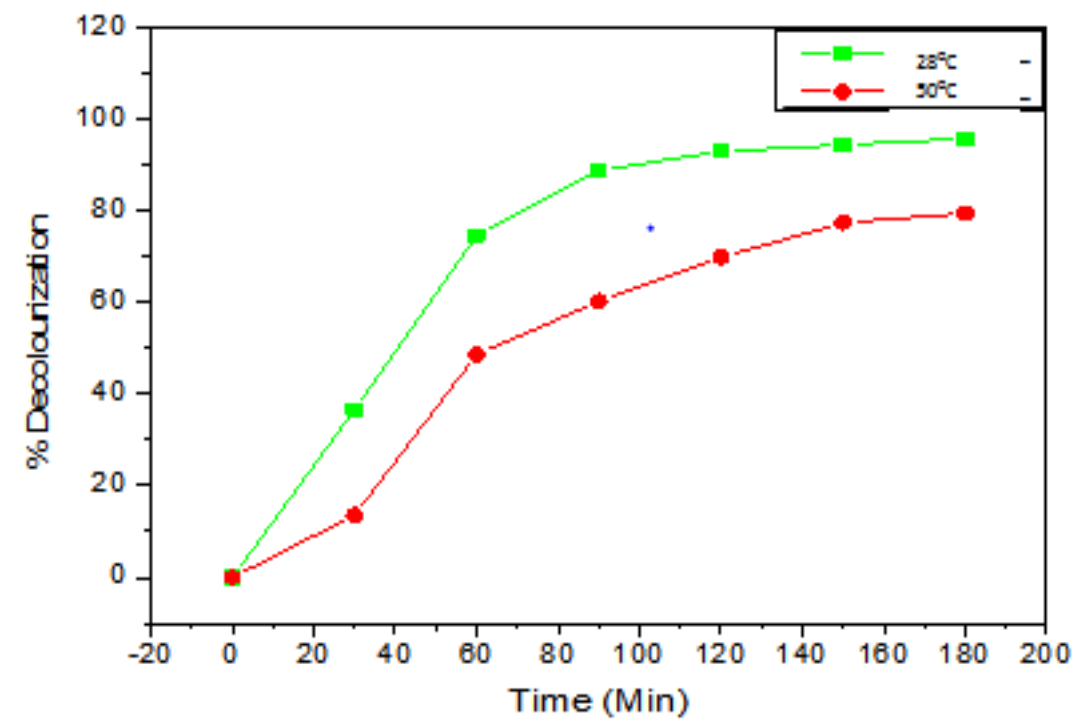

Fig. 5: \% Decolourization at 50mg $/ \mathrm{L}$ Disperse Blue 1 at $28^{\circ} \mathrm{C}$ and $50^{\circ} \mathrm{C}$. $($ current $=1 \mathrm{~A}$, voltage $=$ $5 \mathrm{~V}$, electrolyte $=0.05 \mathrm{molL}^{-1}$ ) using plain graphite electrodes

\subsection{Effect of Current Intensity}

The effect of current intensity on Disperse blue 1 dye using the electrochemical technique was also investigated as shown in figure 5 and 6 below. The current intensity was varied between $1 \mathrm{~A}$ and $3 \mathrm{~A}$. From the figures below, the percentage decolourization was observed to be higher at lower current intensity but as the current intensity increased the degradation pattern became anomalous at a higher concentration as shown in figure 6. Furthermore, it is observed that higher current intensity favours the degradation of the dye at higher concentration because the $95 \mathrm{mg} / \mathrm{L}$ degraded more than the $50 \mathrm{mg} / \mathrm{L}$. All these points to the conclusion that higher current intensity is unfavourable to the degradation of Disperse blue dye majorly because it will lead to higher treatment cost and low treatment efficiency as affirmed in figure 6 that the $95 \mathrm{mg} / \mathrm{L}$ only slightly degraded above the $50 \mathrm{mg} / \mathrm{L}$ at higher current intensity. The reason for this conclusion is because the charge loading for the degradation of Disperse blue dye decreases as the current intensity increases, the over-potential necessary for the generation of chlorine/hypochlorite 
increases as the current intensity increases and the variation of the current intensity affects the electrodes surface reaction with the dye molecules as reported by other authors.

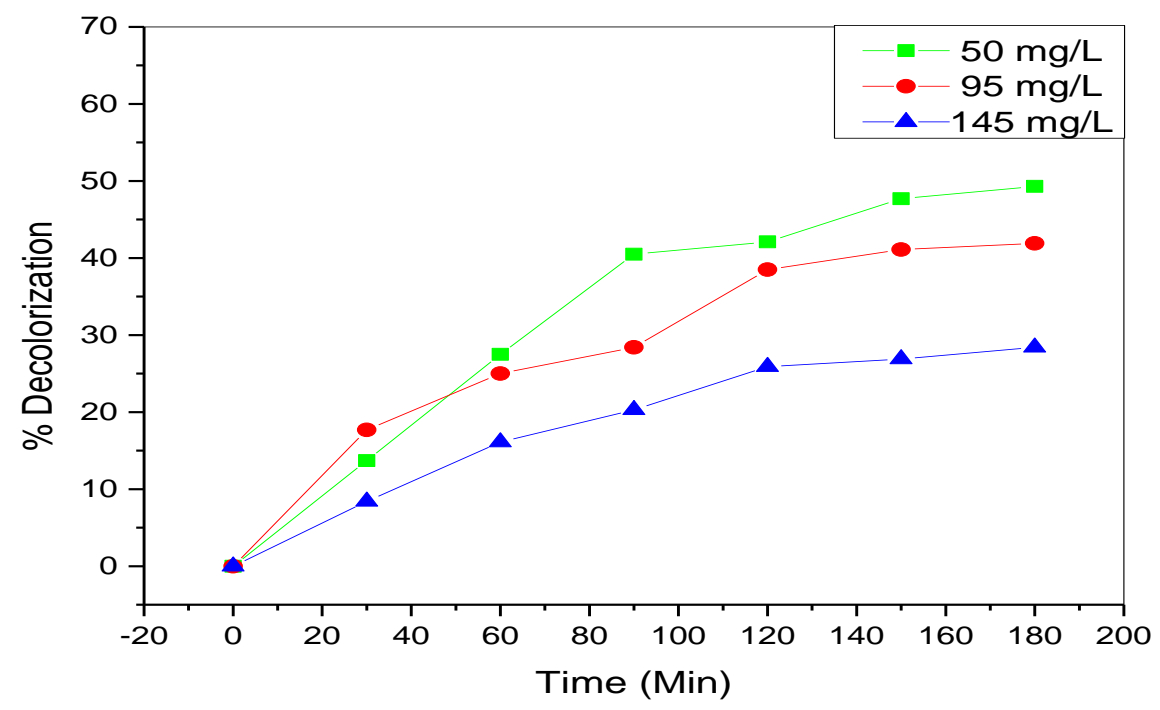

Fig. 6: \% Decolourization of $50 \mathrm{mg} / \mathrm{L}, 95 \mathrm{mg} / \mathrm{L}$ and $145 \mathrm{mg} / \mathrm{L}$ Disperse Blue1under optimal conditions (current $=1 \mathrm{~A}$, voltage $=5 \mathrm{~V}$, electrolyte $=0.05 \mathrm{molL}^{-1}$ ) using plain graphite electrodes

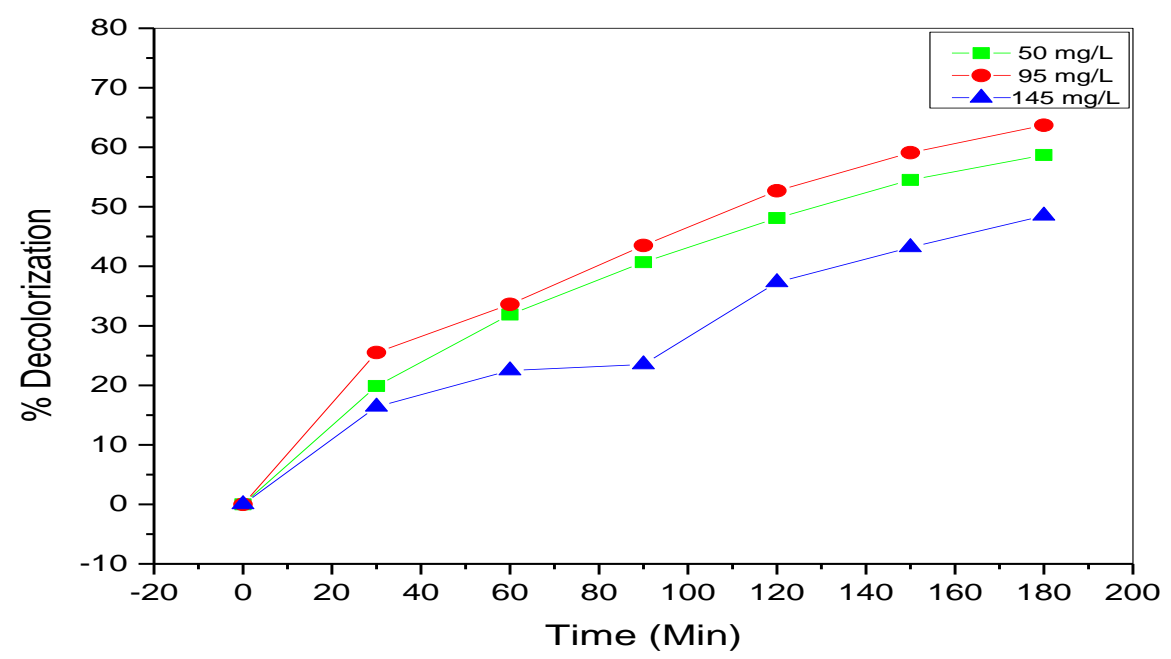

Fig. 7: \% Decolourization of $50 \mathrm{mg} / \mathrm{L}, 95 \mathrm{mg} / \mathrm{L}$ and $145 \mathrm{mg} / \mathrm{L}$ Disperse Blue1under conditions of (current $=3 \mathrm{~A}$, voltage $=5 \mathrm{~V}$, electrolyte $=0.05 \mathrm{molL}^{-1}$ ) using plain graphite electrodes 


\subsection{Conclusion}

The electrochemical treatment technique was used in the degradation of disperse blue1 dye using graphite electrodes, sodium chloride as supporting electrolyte. The effects of various operating parameters were studied with satisfactory results.

At the optimal operational electrolytic conditions (current $=1 \mathrm{~A}$, voltage $=5 \mathrm{~V}$, electrolyte $\mathrm{NaCl}=0.05 \mathrm{~mol} / \mathrm{L}, \mathrm{pH} 4$ and temperature $301 \mathrm{~K}$ ) the degradation of dyeing intermediates was greatly influenced. Increasing the initial concentration and $\mathrm{pH}$ will lead to a corresponding decrease in effluent degradation. The effect of $\mathrm{pH}$ clearly showed that under acidic conditions the dye effluent degradation using this technique was more efficient.

It was evident that variations of temperature and current intensity affected the decolourization process. At lower temperature and current intensity, the degradation of disperse blue1 dye effluent was favourable. UV-Vis study confirmed that the proposed electrochemical degradation process could be an effective method for the degradation of textile dye effluent.

However, further investigation of other effluent parameters such as BOD, COD, TOC, is necessary to ascertain the viability of this technique in the complete degradation of the disperse blue1 dye, as the scope of this work was focused solely on colour removal.

\section{Reference}

[1] Abidin, C Z. A., Fahmi, S., Ong, A., Ahmad, R., Sabri, S. N. (2017). "Treatment of azo dye Acid Orange 52 using ozonation and completed-mixed activated sludge process", School of Environmental Engineering, Universiti Malaysia Perlis, 3, 1-7.

[2] Selvam, K., Shanmuga, M., Yamuna, M., Priya M. (2012). "Decolourization of Azo Dyes and Dye Industry Effluents by Lignin Degrading Fungus" Trametes Versicolor, 32: 667-672.

[3] Sun, Z. P. and Chen, D.H. (2016)."Electrochemical decolourization of reactive brilliant red $\mathrm{X}-3 \mathrm{~B}$ with the $(\mathrm{CeO} 2 / \mathrm{C})-\beta-\mathrm{PbO} 2-\mathrm{PTFE}$ composite electrode". Journal of rare earths, 34(5):507-520

[4] Mabel, J.C., Subathra, M., Shyamala, M., Padmavathy, S. (2013)." Microbial Decolourisation of azo dyes - a comparative analysis". Department of Microbiology, Sourashtra College, Madurai.62: 66-70. 
[5] Merina, P., Manas, B., Maggidi, R. (2016). "Biological decolourization of carcinogenic Azo dye: an ecofriendly approach". Department of industrial biotechnology Bharath University, Chennai, India, 23, 43-56.

[6] Balakrishnan, R. B., Anandkuber, P., Saravanan, Arum, K., Sirasana-Sanba, U. B. (2011)."Treatment of dye effluent by electrochemical and biological processes”.Central electrochemical research institute, Karaikudi, India. 45-120.

[7] Singh, S., Srivastava, V. C., Mall, I. D. (2013). "Multistep optimization and residue disposal study for electrochemical treatment of textile wastewater using an aluminium electrode. International Journal of Chemical Reactor Engineering, 11(1), 1-16.

[8] Usha, N., Murthy, R.B., Mahaveer, D. (2014). Contribution of Electrochemical treatment in textile dye wastewater, World Academy of Science, Engineering and Technology" International Journal of Material and textile Engineering, vol. 8, pp 130-132.

[9] Narjes, J., Kasra-Kermanshahi, R., Mohammad R. S., Amir, H. M. and Sara, G. (2012)."Decolourization of A Textile Reactive Azo Dye Using A Combined Biological-Photocatalytic Process" Process Biochemical, 31:45-56.

[10] Rai, H.S., Bhattacharyya, M.S., Singh, J., Bansal, T.K., Vats, P. Banerjee, U.C. (2005). "Removal of dyes from the effluent of textile and dyestuff manufacturing industry: A review of emerging techniques with reference to biological treatment”. Central Revision Environmental Science Technology, 35: 219-238

[11] Apostol, L.C., Pereira, L., Pereria, R., Gavrilescu, M., Alves, M.M. (2012)."Biological decolourization of xthrane dyes by anaerobic granular biomass", Biodecolourization, 12: 9548-7.

[12] Chen, B.Y., Lin, K. W., Wang, Y. M., Yen, C.Y. (2009). "Revealing Azo Dye Decolourization of Indigenous Aeromonas Hydrophilla," Journal Hazard. Matter. 166:187.

[13] Arun, J., Prasad, A., and Bhaskara, S., Rao K.V. (2010) "Physicochemical characterization of textile effluent and screening for dye decolorizing bacteria" Global Journal of Biotechnology and Biochemistry 5: 80-86.

[14] Dastagir, S., Naga, P., Padma, S. (2014). "Studies on Immobilized Yeast For Decolorization Of Azo Dyes". International journal of scientific \& technology research, volume 3, 182-185. 
[15] Kurbiel, J. (1978). "Removal of Colour, Detergents and Other Refractory Substances from Textile Wastewater", Polish Institute of Meteorology and Water Management. 45: 81-95.

[16] Prakash, K., Anavar, J.N., Yanjerappa, A.N. (2011). Decolourization of textile wastewater by electrochemical method. Department of P.G. Studies and research in Environmental Science Kuvempu University, 2(1):110 -131.

[17] Ponraj, M., Gokila, K., Vasudeo, Z. (2011). "Bacterial decolourization of textile dye-orange3R".Vivekanandha College of Arts and Science for Women, 50: 169-177.

[18] Kushwaha, J. P., Srivastava, V. C., Mall, I. D. (2011). "An overview of various technologies for the treatment of dairy wastewaters". Critical Reviews in Food Science and Nutrition, 51(5), 442-452.

[19] Kushwaha, J. P., Srivastava, V. C., Mall, I. D. (2010). "Organic removal from dairy wastewater by electrochemical treatment and residue disposal". Separation \& Purification Technology, 76, 198-205.

[20] Sun Z P, Chen D H. Electrochemical degradation of reactive brilliant red X$3 \mathrm{~B}$ with the $(\mathrm{CeO} 2 / \mathrm{C})-\beta-\mathrm{PbO} 2-\mathrm{PTFE}$ composite electrode $[\mathrm{J}]$. Journal of rare earths, 2016, 34(5):507-520.

[21] Zhang C. The Research of Treating Dye and Ammonia Nitrogen Wastewater by a New Lead Dioxide Electrode[D].Hefei University of Technology, 2014.

[22] D. Rajkumar, B. J. Song, J. G. Kim, Electrochemical degradation of Reactive Blue 19 in chloride medium for the treatment of textile dyeing wastewater with identification of intermediate compounds, Dyes and Pigments 72 (2007) 1-7 